\title{
Somatik Belirti Bozukluğu: Tarihsel Süreç ve Biyopsikososyal Yaklaşım
}

\section{Somatic Symptom Disorder: Historical Process and Biopsychosocial Approach}

\author{
Şahabettin Çetin 1 (1D, Gülfizar Sözeri Varma ${ }^{2}$ (D)
}

\section{$\ddot{0} z$}

Somatizasyon zihin-beden ilişkisinin derinden hissedildiği bir kavramdır. Ortaya çıkmasında biyolojik, bilişsel, psikodinamik ve kültürel etmenlerin katkısı bulunmaktadır. Bir ruhsal bozukluğun belirtisi olarak somatizasyonun tanımı, oluş nedenleri, sürdürücü etkenleri ve tedavisi çok yönlü ve karmaşıktır. Bu bozukluk tarihsel süreçte üzerinde en çok tartışllan konulardan biridir. DSM'nin son baskısı ile birlikte "Somatik Belirti Bozuklukları ve İlişkili Bozukluklar" başlğı̆la sınılandırmada yer almıştır. Somatik belirti bozukluğu yaşam kalitesinin azalmasına, yeti kaybına ve sağık hizmetlerinde yüksek maliyete yol açmaktadır. Bu haliyle hastalıkla ilgili belirtileri biyopsikososyal bütünlük içinde ele almak kaçınımaz olmaktadır. Bu çalışmada somatik belirti bozukluğunun tarihsel sürecinin özetlenmesi, oluş nedenlerinin ve temel tedavi yaklaşımının biyopsikososyal bütünlük içinde sunulması amaçlanmışıır.

Anahtar sözcükler: Somatoform bozukluklar, sınıflandırma, psikosomatik tıp

\section{Abstract}

Somatization is a concept in which the mind-body relationship is deeply felt. Biological, cognitive, psychodynamic and cultural factors contribute to its emergence. The definition of somatization as a symptom of a mental disorder, its etiopathogenesis, maintenance factors and treatment are multifaceted and complex. This is one of the most discussed mental disorders in the historical process. It was included in the classification with the title of "Somatic Symptom Disorders and Related Disorders" with the last edition of DSM. Somatic symptom disorder causes a decrease in the quality of life, loss of disability and high costs in health services. Therefore, it is necessary to consider the symptoms of the disease in a biopsychosocial integrity.ln this study, it is aimed to summarize the historical process of somatic symptom disorder, to present its causes and basic treatment approach in biopsychosocial integrity.

Keywords: Somatoform disorders, classification, psychosomatic medicine

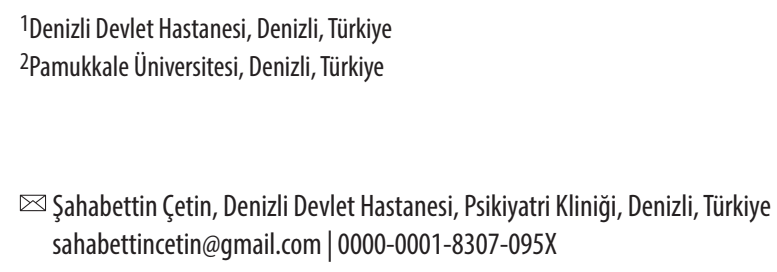

Geliş tarihi/Received: 22.02.2021 | Kabul tarihi/Accepted: 09.05.2021 |Çevrimiçi yayın/Published online: 24.06.2021 
SOMATIZZASYON psikolojik sıkıntıların somatik belirtiler yoluyla ifade edilmesi olarak tanımlanabilir. Sözel iletişimin olmadığı bebeklik dönemlerinde olağan bir iletişim biçimi olan somatizasyon, dilin gelişimi ile birlikte yerini sözel ifadeye terk etmektedir. Somatizasyon beden-zihin etkileşiminin derinden hissedildiği bir alan olup ortaya çıkışında ve sürmesinde biyolojik, bilişsel, psikodinamik, kültürel etmenler rol oynamaktadır. İnsanoğlu varolduğundan bu yana somatik olarak yaşanan ve fiziksel bir hastalıkla aç1klanamayan belirtilerin varlığ1 söz konusu olmuştur (Lipowski 1988). Tarihsel süreci histeriye kadar uzanmakla birlikte sınıflandırma sistemlerinde en çok tartış1lan konulardan biridir. DSM'nin son baskısı (DSM-5) ile birlikte bu hastalık grubu "Somatik Belirti Bozuklukları ve İlişkili Bozukluklar” olarak tanı sınıflandırmasında yerini almıştır (APA 2013). Yıllar içerisinde önemli dönüşümler geçirmiş olan kavramın son tanımlaması klinik ve akademik çevrede bir hayli dikkat çekmiştir (Hüsing ve ark. 2018). Bununla birlikte hem gündelik klinik pratikte hem de akademik yazında "somatoform", "somatizasyon" gibi kavramların kolaylıkla geride bırakılamadığı da göze çarpmaktadır.

Somatik belirti bozukluğu yaşam kalitesinin azalmasına ve yeti kaybına yol açmakta, sağlık hizmetleri için harcanan maliyeti artırmaktadır. Somatizasyon bir ruhsal bozukluk belirtisi olarak karşımıza çıktığında ve tanımlama ile ilgili kavram karmaşası, oluş nedenleri, sürdürücü etkenler göz önüne alındığında hastaların biyopsikososyal bütünlük içinde ele alınması kaçınılmazdır (Morabito ve ark. 2020). Tedavide psikoeğitim, psikoterapiler ve psikofarmakolojik ajanların kullanımı önerilmektedir. Bu yöntemlerin hiç birisi tek başına yeterli olmadığı gibi birçok etmen birlikte değerlendirilmelidir (D’Souza ve Hooten 2021). Her yönüyle karmaşık bir doğaya sahip gibi görünen bu kavramların farklı yönleriyle ele alınması daha açık anlaşılmasına katkı sağlayacaktır. Psikolojik kökenli somatik belirtilerin ele alınışı ve sınıflandırma sistemlerindeki yeri histeriden bu yana tartı̧̧ma konusu olmuştur. $\mathrm{Bu}$ yazıda somatik belirti bozukluğunun sinıflandırma sistemlerindeki yerinin gözden geçirilmesi, hastalığın anlaşılmasında ve tedavisinde biyopsikososyal etmenlerin birlikte ele alınmasının öneminin vurgulanması amaçlanmıştır.

\section{Tarihsel süreçte somatizasyon ve somatik belirti bozukluğu}

Somatizasyon, insanlığın eski zamanlarından bu yana hekimler tarafindan anlaşılmaya çalışılan bir kavramdır. Melankoli ve histeri kavramlarının M.Ö. 2600 yıllarında Misırlılar ve Sümerliler tarafından kullanıldığı bilinmektedir. Uzun yıllar histeri, melankoli ve hipokondriazis kelimeleriyle karışı biçimde birbirinin yerine kullanıla gelmiştir. Çin ve Hint tıbbı zihin ve bedeni iç içe geçmiş kavramlar olarak görmüştür. Çin tıbbında duygulardaki (sevinç, öfke, üzüntü, yas, anksiyete, korku, ürkme) eksiklik ya da fazlalığın hastalıklara yol açtığı kabul edilmiştir. Hint tıbbında ise tutkunun göğüste, bilgisizliğin karın boşluğunda olması gibi belli kişilik özelliklerinin bazı organlara yerleştiği, güçlü duyguların özel davranışlara yol açtığına inanılmıştır (Hollfied 2005). M.Ö.1900 yıllarında Kahun tabletlerinde uterusun yer değiştirip başka organlarda yer almasının hastalıklara yol açtığı ileri sürülmüştür. Somatizasyon denilince ilk akla gelen ve en çok tanım karmaşası yaşanan kavramlardan biri şüphesiz histeridir. Histeri Yunanca "hysteron" (uterus) kelimesinden 
türemiştir (Ünal 1999). Hipokrat, histeriyi kadınlara özgü bir hastalık olarak nitelendirmiş, 17. yüzyıla kadar histerinin uterusun baskılanmayan istekleri nedeniyle vücutta gezinmesi sonucu oluşan bir hastalık oluştuğuna inanılmıştır (Hollfied 2005).

Ortaçağın karanlık döneminde ruhsal ve fiziksel hastalıklar büyüsel nedenlere bağlanmış, histeri hastalarının ruhlarını şeytana sattığı inancı hakim olmuştur. Bu yıllar ilahi cezanın bilimsel sorgulamanın yerini aldığı dönemlerdir. Rönesans ile birçok alanda olduğu gibi tıp ve ruhsal hastalıkların ele alınması konusunda aydınlanma yaşanmıştır. 17. yüzyılda santral sinir sistemi hastalıkları ile ilgili bilgiler artmış, açıklanamayan bir takım belirtilerin beyinden kaynaklanıyor olabileceği fikri ortaya çıkmıştır (Hollfield 2005). Nörolojinin babası sayılan Thomas Willis (1621-1675), kadında histeriyi, erkekte hipokondriazisi beynin bir bozukluğu olarak görmüştür. Thomas Sydenham (1624-1689) histeri ve hipokondriazisin bedenden ziyade zihnin bir bozukluğu olduğu görüşüne önemli katkılarda bulunmuştur. George Cheyne (1617-1743) "İngiliz Hastalığı” terimini kullanmış, histeri ve hipokondriazisin beyin ve/veya zihnin hastalığı olduğunu yazmıştır. William Cullen (1721-1790) "neurosis" kelimesini ilk kullanan kişi olmuştur. 19. yüzyılda hipokondriazisin karından başlayıp beyine ilerleyen bir enflamasyon olduğu görüşü ortaya çıkmıştır. Bu yüzyıl histeri üzerine yoğun araştırmaların yapıldığ̣ yıllar olmuş, beyinde veya bedende bu bozuklukla ilgili anatomik patolojiler gösterilemeyince histerinin işlevsel ve karmaşık bir hastalık olduğu düşünülmeye başlanmıştır. Paris Salpetriere Hastanesinde hekimlik yapan Jean-Martin Charcot histerinin tanı ve tedavisinde hipnozu kullanmıştır. Charcot ve öğrencileri histerinin oluş mekanizmaları ve tedavisinde önemli katkılarda bulunmuşlardır (Ünal 2002, Hollfield 2005). Freud'un önce hipnoz, sonra serbest çağrışımla başlayan histeriyi tedavi etme arayışları psikanalitik kuramın oluşumuna zemin hazırlamıştır. Joseph Breuer ile birlikte hazırladıkları "Histeri Üzerine Çalışmalar" isimli monografi 1895 yılında yayınlanmıştır (Breuer ve Freud 1895).

Somatizasyon terimini ilk olarak kullanan kişi Alman psikanalist Wilhelm Stekel, somatizasyon bozukluğu olarak bilinen klinik tabloyu tanımlayan ilk kişi ise Paul Briquet olmuştur. İleriki yıllarda onun anısına somatizasyon bozukluğu "Briquet Sendromu" olarak da tanımlanmıştır (Öztürk ve Uluşahin 2016). Zamanla histeri kavramının bir kişilik ya da karakter tipi, konversiyon tepkisi, fobi ve anksiyete ile giden psikonevrozların yerine kullanılması, hatta gündelik dilde hakaret içeren bir ifade olarak yer bulması günümüzde bu kavramdan uzaklaşılmasına yol açmıştır.

\section{Günümüz sınıflandırma sistemleri içinde somatizasyon}

Somatizasyonun tanımlanması, hastalıkların sinıflandırılması tarihi boyunca sorun teşkil etmiştir. Günümüzde kabul görmüş, yaygın olarak kullanılan -ICD (International Classification of Diseases and Related Health Problems, Dünya Sağlık Örgütü) ve DSM (Diagnostic and Statistical Manual of Mental Disorders, Amerikan Psikiyatri Birliği) olmak üzere- iki temel sınıflama sistemi bulunmaktadır. ICD'nin 6. versiyonu ölüm nedenleri dışında, hasar bırakıcı veya düşkünleştirici nedenleri de içerecek şekilde genişletilmiş; ruhsal hastalıklar "Ruhsal, Psikonevrotik ve Kişilik Bozuklukları" başlığı altında sınıflandırmaya 
dahil edilmiştir. ICD-10'da somatizasyon ile ilişkili bozukluklar "Nevrotik, Stresle İlişkili ve Somatoform Bozukluklar” grubunda yer almaktadır. DSM'nin 2. Baskısında tıbbi olarak açıklanamayan belirtiler "Nevrozlar, Psikofizyolojik Bozukluklar ve Özel Belirtiler" bölümünde yer almıştır. Nevrozlar histerik nevroz, nevrasteni, depersonalizasyon, hipokondriazis ve diğer nevrozlar olarak ayrılmıştır (Kırpınar 2019). Somatizasyon bozukluğu tanımı ilk olarak DSM-3'te tanı sınıflandırma sisteminde yerini almıştır (APA 1980). Bununla ilişkili bir başka bozukluğu ifade eden ve psikolojik çatışmalar nedeniyle fiziksel enerjinin bastırılması sonucu oluştuğu öne sürülen konversiyon terimi psikanalitik teoriye dayanan ve bu sinıflandırma sistemine giren ilk terim olmuştur. Somatizasyon bozukluğu DSM-4'te Somatoform Bozukluklar grubunda sınıflandırılmıştır (APA 2000). Somatizasyon bozukluğu 30 yaşından önce başlayan; tekrarlayıcı, multipl, klinik olarak anlamlı ağrı, gastrointestinal, cinsel ve psödonörolojik belirtilerle seyreden bir bozukluk olarak tanımlanmıştır. DSM-5'te somatoform bozukluklar somatik belirti bozuklukları ismiyle değiştirilmiş ve tanı ölçütlerinde değişikliklere gidilmiştir (APA 2013) (Tablo 1, 2).

Önceki tanı ölçütlerinin özellikle psikiyatri dışı klinisyenler tarafindan anlaşılması ve kullanılmasının güç olması değişikliğe duyulan ihtiyacın nedenlerinden biridir (Mayou 2014). Çok sayıda sisteme ait belirtilerin bildirilmesini gerektiren kısıtlayıcı ve katı ölçütler olması eleştirilmiştir (Smith ve Józefowicz 2012). Bu ölçütler hastaların somatik yakınmaları için herhangi bir tıbbi kaynak bulunmaması gerekliliği içermekte ve zihin-beden dualizmine ilişkin eski bir tartışmayı klinik pratiğe taşımaktadır (Dimsdale ve ark. 2013). Tüm bunlar düşünüldüğünde birinci basamakta somatizasyon bozukluğu tanısının prevalansının çok düşük olması şaşırtıcı değildir (Hüsing ve ark. 2018). Aksine somatik belirti bozukluğu tanısının daha yüksek bulunabileceği düşünülebilir. Nitekim genel hastane başvurularından çok merkezli olarak yürütülen bir araştırmada katılımcıların \%33,8’i somatik belirti bozukluğu tanısı aldığı bildirilmiştir (Cao ve ark. 2020).

Ancak bu yeni ölçütler de kliniğe bazı yansımaları açısından eleştirilmiştir. Temel eleştiri noktası kronik belirtiler ile giden tıbbi hastalığı olan bir kişinin hatalı olarak mental bir bozukluk tanısı alma olasılığının yüksek olmasıdır. Tanı ölçütlerindeki en dikkat çeken

Tablo 1. DSM-IV Somatoform Bozukluklar ve DSM-5 Somatik Belirti Bozukluğu ve İlişkili Bozukluklar

\begin{tabular}{ll}
\hline DSM-IV (Somatoform bozukluklar) & DSM-5 (Somatik belirti bozukluğu ve ilişkili bozukluklar) \\
\hline Somatizasyon Bozukluğu & $\begin{array}{l}\text { Somatik Belirti Bozukluğu } \\
\text { Ağrının baskın olması ile giden }\end{array}$ \\
\hline Farklılaşmamış Somatoform Bozukluk & Hastalık Anksiyetesi Bozukluğu \\
\hline Konversiyon Bozukluğu & Konversiyon Bozukluğu \\
\hline Ağrı Bozukluğu & \\
$\begin{array}{l}\text { Psikolojik Etkenlerin Eşlik Ettiği } \\
\text { Hem Psikolojik Etkenlerin, Hem de Genel Tıbbi Durumun Eşlik } \\
\text { Ettiği }\end{array}$ & Diğer Tıbbi Durumları Etkileyen Psikolojik Etkenler \\
\hline Hipokondriazis & Yapay Bozukluk \\
\hline Vücut Dismorfik Bozukluğu & Belirlenmiş Diğer Bir Somatik Belirti ve Ilişskili Bozukluk \\
\hline Başka Türlü Adlandırılamayan Somatoform Bozukluk & Belirlenmemiş Diğer Bir Somatik Belirti ve illişkili Bozukluk \\
\hline
\end{tabular}


Tablo 2. DSM-IV Somatizasyon Bozukluğu ve DSM-5 Somatik Belirti Bozukluğu tanı ölçütleri

\begin{tabular}{|c|c|}
\hline DSM-IV & DSM-5 \\
\hline $\begin{array}{l}\text { Birkaç yıllık bir dönem içinde ortaya çıkan, tedavi arayışları ya da } \\
\text { toplumsal, mesleki ya da işlevselliğin diğer alanlarında bozulma ile } \\
\text { sonuçlanan ve } 30 \text { yaşından önce başlayan çok sayıda fiziksel yakınma } \\
\text { öyküsünün olması }\end{array}$ & $\begin{array}{l}\text { Sıkıntı veren ya da günlük yaşamı önemli derecede etkileyen } 1 \\
\text { veya daha çok somatik belirti varlığı }\end{array}$ \\
\hline $\begin{array}{l}\text { Aşağıdaki tanı ölçütlerinden her biri karşılanmış olmalıdır, herhangi } \\
\text { tek bir belirti bu hastalığın gidiş̧ sırasında herhangi bir zamanda } \\
\text { ortaya çıkabilir. } \\
\text { Dört ağrı belirtiu } \\
\text { İki gastrointestinal belirti } \\
\text { Bir cinsel belirti } \\
\text { Bir psödonörolojik belirti }\end{array}$ & $\begin{array}{l}\text { Aşağıdakilerden en az biri ile kendini gösteren, somatik } \\
\text { belirtiler ya da bunlara eşlik eden sağlıkla ilgili anksiyete ile } \\
\text { ilişkili aşırı düzeyde düşünceler, duygular ya da davranışlar } \\
\text { Kiş̧inin belirtilerinin önemiyle orantısız, süreklilik gösteren } \\
\text { düşşünceler } \\
\text { Sağlıkla ya da belirtilerle ilişkili sürekli yüksek düzeyde } \\
\text { anksiyete } \\
\text { Bu belirtilere ya da sağlık anksiyetesine aşırı zaman ve içsel } \\
\text { güç harcama }\end{array}$ \\
\hline
\end{tabular}

Aşağıdakilerden biri vardır:

Yeterli bir incelemeden sonra B ölçütündeki belirtiların hiçbiri bilinen genel bir tıbbi durum ya da bir maddenin doğrudan etkileri ile tam açıklanamaz.

İlişkili genel bir tıbbi durum olsa bile fizik yakınmalar ya da bunların Herhangi bir somatik belirti sürekli olarak bulunmasa da belirti gösteriyor olma durumu süreklilik gösterir (6 aydan uzun) bir sonucu olarak ortaya çıkan toplumsal ya da mesleki bir bozulma, öykü, fizik muayene ya da laboratuar bulgularına göre beklenenden çok daha fazladır.

Bu belirtiler amaçlı olarak ortaya çıkarılmamakta ya da bu tür belirtileri varmış gibi davranıımamaktadır.

\author{
Ağrının baskın olduğu tip (önceki adı ağrı bozukluğu) \\ Süregiden \\ Ağır olmayan/orta/ağır
}

düzenlemenin belirtilerin tıbbi olarak açıklanamayışından ziyade kişinin düşünce, duygu ya da davranışlarındaki etkilerine odaklanması olduğu vurgulanmaktadır (Mayou 2014). Bu değişiklik, belirtileri tıbbi olarak açıklanamayan kişilerin yalnızca bu nedenle bir ruhsal hastalık tanısı almasının önüne geçebilmesi açısından gerekli olabilir. Ancak ciddi fiziksel hastalığ1 olan bireylerin değerlendirilmesinde karmaşaya yol açacağ 1 da belirtilmektedir (Mayou 2014, Barsky 2016). Frances'a (2013) göre bu ölçütler kullanıldığında kanser hastalarının \%15’i, kalp hastalığı olanların \%15’i, irritabl bağırsak sendromu ve kronik yaygın ağrı hastalarının \%25’i somatik belirti bozukluğu olarak nitelendirilebilir. Genel popülasyonda da hatalı pozitif tanı alma oranı \%7’ye yaklaşacağ

Bununla birlikte tanı ölçütlerindeki değişikliklerin konuyla ilgili geçmiş literatür ile karşılaştırmak açısından da çeşitli zorluklara yol açacağı düşünülmektedir. Örneğin eski ölçütlerdeki "hipokondriazis" ile DSM-5'te tanımlanan "hastalık anksiyetesi bozukluğu" arasındaki benzerlik ve farklılıkları ayırt etmek gerekmektedir (Barsky 2016). Sahada çalışan hekim ve terapistlerin tanımlaması ve isimlendirmeyle ilgili karmaşa da sürmektedir. Deneyimli terapistlerin somatik belirti bozukluğu tedavisine bakışının değerlendirildiği çalışmada katılımcıların aynı kavramı "fonksiyonel", "somatoform" ya da "psikosomatik" gibi terimlerle tanımladıkları anlaşılmıştır (Weigel ve ark. 2020). Görüldüğü üzere somatik 
belirtilerin psikiyatrik olarak sınıflandırılması üzerinde çok çaba harcanmıştır. Buna karşın pek çok açıdan eleştiriler ve farklı görüşler kavramın gelişimine katkı sağlamaya halen devam etmektedir.Bu alandaki sınıflandırma karmaşasının önemli bir nedeni de hastalığın oluşumunda çok farklı etmenlerin önemli rol oynaması olabilir. Almanya'da yapılan bir çalışmaya göre genel halkın büyük kısmı somatik belirti bozukluğunun en olası nedeninin iş stresi olduğunu düşünmektedir (Knesebeck ve ark. 2020). Bozukluğun oluş nedenlerinin çok yönlü oluşu klinik değerlendirmeyi de zorlaştırmakta, tıbbi, ekonomik ve sosyal yönleri olan çeşitli açmazlar ortaya çıkmaktadır. Morabito ve ark. (2020) göre alt branşlaşmanın artması, hekimlerin olası tıbbi durumları atlama konusunda hissettiği baskı ve biyopsikososyal çerçevenin gözden kaçırılması bu zorluğun nedenlerini oluşturmaktadır. Gündelik stresin yanı sıra çok sayıda biyolojik, kültürel ve psikolojik nedenin bu bozukluğa yol açabileceği bilinmektedir.

\section{Somatik belirti bozukluğunda etiyopatogenez}

\section{Biyolojik nedenler}

Hipo-talamo-pituiter adrenal (HPA) eksen stres yanıtında önemli bir işleve sahiptir. Depresyonda HPA eksenin fazla etkinleşmesi söz konusu iken somatizasyonda hipokortizolizm olduğu belirtilmektedir (Heim ve ark. 2000, Dinan 2001). Bu hastalarda uzun süreli stres maruziyeti ve düzenleyici $T$ hücrelerinin aşırı birikiminin HPA ekseninde tükenmeye yol açtığı ileri sürülmüştür (Pukhalsky ve ark. 2008). Depresyon ve ağrının benzer biyolojik yolakları kullandığı, ağrı yolaklarındaki anahtar nörotransmitterlerin serotonin ve noradrenalin olduğu bilinmektedir (Ball ve ark. 2011). Somatoform bozukluklarda yüksek ağr1 skorlar1 ile 5-hidroksi indol asetik asit (5-HIAA) ve triptofan düzeyleri arasında negatif ilişki bildirilmiştir (Schwarz ve ark. 1999). Triptofan yıkımında rol alan enzimlerin aktivitesinde stres ve inflamatuar süreçlerin etkisiyle artış olduğu; bu yolun sonunda nörotoksik etkisi olduğu bilinen kinürenin ve kinolinik asit maddelerinin artıp, nöroprotektif olduğu bilinen kinürenik asidin azaldığı gözlenmiştir. Somatizasyon hastalarında plazma triptofan düzeylerinin düşük, kinürenin/kinürenik asit ve kinürenin/triptofan oranlarının yüksek olduğu bildirilmiştir (Anderson ve ark. 2012). Triptofan metabolitleriyle ilgili bulguların uzun süreçte de devam ettiği, somatoform bozukluk hastalarında 12 haftalık değerlendirilmesinde de zaman içinde değişim göstermediği anlaşılmıştır (Krause ve ark. 2019). Somatik belirti bozukluğunda oksidatif stres parametrelerinin de yükseldiği gösterilmiştir (Sahin ve ark. 2019).

Somatizasyon bozukluğunda görülen hastalık davranışı, özgün olmayan somatik belirtiler ve ağrılı uyarana duyarlılık artışında proinflamatuar süreçlerin etkili olabileceği ileri sürülmüştür (Rief ve ark. 2010). Uzun süre stresli yaşam olaylarına maruz kalan kişilerdeki proinflamatuar aktivasyon ile anterior singulat korteks aktivitesi arasında ilişki gözlenmiştir. Dikkat ve emosyon arasında köprü görevi gören anterior singulat korteksteki aktivite artışının istenmeyen uyaran ve somatik duyumlara karşı duyarlılık artışına yol açtığı ileri sürülmektedir (Harrison ve ark. 2009). Bir meta-analiz çalışmasına 
göre somatizasyon bozukluğu olan hastalarda beş nöronal alan ile ilgili farklılıklar ön plana çıkmıştır: premotor ve suplementer motor korteksler, orta frontal gyrus, anterior singulat korteks, insula ve posterior singulat korteks (Boeckle ve ark. 2016). Farklı çalışmalarda ise nükleus kaudatusta hacim artı̧ı, amigdala ve non-dominant hemisferde hipoperfüzyon olduğu ortaya konmuştur (Hakala ve ark. 2004, Atmaca ve ark. 2011). Ayrıca istenmeyen uyaranlar verildiğinde anterior singulat korteks ve insulada aktivite artışı gözlenmiştir (Atmaca 2012). Bir PET çalı̧̧masında ise şiddetli somatizasyonu olan hastalarda putamen ve nükleus caudatusta düşük glukoz metabolizması saptanmıştır (Hakala ve ark. 2006). Pan ve ark. (2021) çalışmasında somatik belirti bozukluğu olan kişilerde görülen felaketleştirme ve anksiyetenin dorso-medial prefrontal korteks gri cevher hacmi ile ilişkili olduğu gösterilmiştir. Yakın tarihli bir sistematik derlemeye göre somatoform bozukluklarda yapısal nörogörüntüleme çalışmalarının bulgularından kesin bir sonuca varmak zor görünmektedir. Yine de bilişsel kontrol, emosyon düzenleme ve işleme, stres ve somatik-viseral algı ile ilgili beyin ağlarında değişiklikler olduğu ifade edilmektedir (Rossetti ve ark. 2021).

Ağrı yalnızca bir duyu değil, çok yönlü bir deneyimdir. Nosisepsiyon, doku hasarına yol açabilecek uyaranlara ilişkin duyu bilgisini ileten afferent nöronal aktiviteyi tanımlarken, ağrı kortikal aktiviteyi gerektiren ve nosisepsiyon yokluğunda da oluşabilen bilinçli bir deneyimdir (Kidd ve Urban 2001). Somatizasyon hastalarının seçici algılama ile somatik duyumlarını abarttıkları ve hastalık yönünde yorumladıkları düşünülmektedir. Bu kavram "somatosensoryal amplifikasyon" adıyla bir bilişsel tarz olarak tanımlanmıştır (Barsky 1992). Somatizasyona yatkın olan bireylerde aşırı duyarlı bir nöral ağ olduğuna dair nörobiyolojik varsayımı tanımlamak için "merkezi duyarlılık" terimi öne sürülmüştür. Merkezi duyarlılaşmaya bağlı olarak zararsız, hafif uyaranlar nosiseptif spesifik dorsal boynuz hücrelerini harekete geçirir. Bunun klinik sonucu normalde ağriya yol açmayacak bir uyaranla ağrı deneyiminin yaşanmasıdır. Bourke ve ark. (2015) merkezi duyarlılaşmada nöral ağ ile ilgili öne çıkan yapıların çoklu ağrı girdisi, tehdit algılama, emosyonel düzenleme ve motivasyonla ilgili olan insula ile belirgin olan uyaranın fark edilmesinde (saliency detection) rol alan striatum olduğunu ifade etmiştir. Bir başka biyolojik mekanizma olarak limbik sistem aşırı duyarlılığı ve hipokampal hacimdeki azalma ile çocukluk çağı travmaları arasındaki ilişki de merkezi duyarlılaşma fenomeniyle ilgili görünmektedir (Dannlowski ve ark. 2012). Bir başka araştırmada somatik belirti bozukluğu olan katılımcılara ağrılı uyaran verildiği esnada meydana gelen kortikal aktivite değerlendirilmiştir. Ortalama ağrı eşiği seviyesi ile sol orta oksipital girus aktivitesi ve somatosensoryel amplifikasyon seviyesi ile sağ angular girus aktivitesi arasında korelasyon saptanmıştır (Colak ve ark. 2021).

Yapılan genetik çalışmalar özellikle monoaminerjik sistemle ilgili genetik değişikliklerin ilişkisinin olabileceğini düşündürmekte ancak ortak bir genetik kökene işaret etmekten uzak görünmektedir. Bu rolün daha iyi anlaşılabilmesi için belirtilerin gelişimindeki özgün süreçlerin, farklı biyolojik ve psikososyal etkenler arasındaki etkileşimlerin dikkate alınması gerekmektedir (Rief ve ark. 2010). Somatik belirtive ilişkili bozukluklarda beyinde yer alan değişikliklerin olası genetik nedenleri üzerine tartışma açan bir yazıda, bu hasta grubunda özellikle erken dönemde maruz kalınan travma öyküsünün oldukça yüksek olduğundan yola 
çıkılarak travmaların yol açtığı epigenetik değişikliklerin açıklayıcı olabileceği vurgulanmıştır (Frodl 2016). Bir araştırmada somatik belirti bozukluğu grubunda glukokortikoid reseptör geninde (NR3C1) hipometilasyon, depresyon grubunda hipermetilasyon olduğu bulunmuştur (Çetin 2018). Bu durum iki bozukluk arasındaki HPA aksı fizyolojisindeki farklılıkla ilgili olabileceği şeklinde yorumlanmıştır.

\section{Kültürel ve psikolojik nedenler}

Kültürel psikiyatrinin en çok tartıştığı konulardan biri de psikososyal stresle ilişkili somatik ifadelerdir. Etnik köken, düşük eğitim düzeyi, düşük sosyoekonomik durum ve kadın cinsiyetinde olmak somatizasyon ile ilişkili öne çıkan sosyal etmenlerdir (Escobar ve Canino 1989, Kirmayer ve Young 1998). Örneğin, somatizasyonun kültürel bağlamda değerlendirilmesini amaçlayan bir çalışmaya Amerikalı ve Koreli gönüllüler katılmıştır. Koreli katılımcıların stresli durumlarla ilişkisini anlatırken daha çok bedenle ilgili kelimeler kullandıkları, duyguları anlatırken somatik ifadelerin kullanıldığı metinler okutulduğunda daha çok sempati hissettikleri saptanmıştır (Choi ve ark. 2016). Yine de psikolojik rahatsızlığın farklı somatik belirtilerle ortaya çıkması batı toplumları da dahil olmak üzere tüm kültürlerde karşımıza çıkabilir (Beyazyüz ve Göka 2013). Kirmayer ve Ryder (2016) somatizasyonun batılı olmayan toplumlara ait bir görünüm olduğu iddiasının eskide kaldığını ifade etmektedir. Bu iddianın eski çalışmaların gruplarla aşırı genelleme yapmalarından kaynaklandığını öne sürmüşlerdir. Yazarlar somatizasyonun batı kültürlerinde de ruhsal sıkıntının oldukça yaygın bir anlatım biçimi olduğunu belirtmişlerdir.

Pennebaker ve Watson (1991), çevrede anlamlı bilginin yokluğunda dikkatin içsel uyaranlara odaklanma eğiliminde olacağını, bu durumun belirti bildirmede artışa neden olabileceğini öne sürmüşlerdir. Buradan yola çıkarak somatizasyonda en riskli grubun gelişim dönemlerinde duyguları dışa vurmanın ayıplandığı toplumsal ortamlarda yetişen kişiler olduğu belirtilmektedir (Berry ve Pennebaker 1993). Travmatik yaşam olayları somatik belirti bozukluğu gelişiminde etkilidir. Ford (2000), somatizasyon bozukluğu hastalarının çoğunun sosyopati ve alkolizmin söz konusu olduğu kaotik ailelerden geldiğini kaydetmiştir. Bir meta-analiz çalışmasında cinsel istismar öyküsü ile fonksiyonel gastrointestinal sendrom, non-spesifik kronik ağrı, non-epileptik nöbet ve kronik pelvik ağrı arasında anlamlı ilişki olduğu bulunmuştur (Paras ve ark. 2009). Ülkemizde yapılan bir çalışmada somatizasyon bozukluğu olan 40 kadın hastanın kontrollere göre çocuklukta daha fazla travmatik deneyim (emosyonel ihmal, emosyonel istismar ve fiziksel istismar) yaşadığı gösterilmiştir (Taycan ve ark. 2014).

Bilinçdışı cinsel dürtülerin doyum yolu olarak da ağrının algılanışı ve ifade edilişi etkilenebilir. Ağrıda kullanılan başlıca ego savunma düzenekleri arasında bastırma, izolasyon, kendine çevirme ve konversiyon sayılabilir (Algül ve Tütüncü 2013). Bağlanma biçimleri açısından bakıldığında somatizasyon bozuklukları olan bireylerde güvensiz bağlanma insidansı daha yüksek bulunmuştur. Bu hastalardaki kişilerarası ilişkiler ve sağlık bakımı ile ilgili sorunların güvensiz bağlanma ile bağlantılı olabileceği düşünülmektedir (Waller ve ark. 2004). Bir çalışmada çocukların 18 aylıkken değerlendirilen maternal duyarlılık düzeyi ile 
5 yaşında değerlendirilen somatizasyon düzeyleri arasında negatif ilişki saptanmıştır. Aynı çalışmada erişkinlerde güvensiz bağlanma ile somatizasyon arasında, anksiyöz bağlanma ile sağlık anksiyetesi arasında da ilişki olduğu belirlenmiştir (Maunder ve ark. 2017). Kişilik özellikleri de somatizasyonile ilişkili bozuklukların gelişmesini etkileyebilir. Borderline kişilik bozukluğu olan hastalarda somatizasyon bozukluğu prevalansı yüksek olarak bulunmuştur. Bu ilişkinin her iki klinik grubun da sosyal ilişkilerinde benzer patern gösteriyor olmasının bir yansıması olabileceği yorumu yapılmaktadır (Mai 2004). Ayrıca bir sistematik derlemeye göre antisosyal kişilik bozukluğu olanlarda da somatik belirti bozukluğu sıklığının fazla olduğu, bu durumun serotonin metabolizmasıyla ilgili genetik nedenlerden kaynaklanıyor olabileceği belirtilmiştir (Espiridion ve Kerbel 2020)

Hasta rolü, normal rahatsızlık davranışına belirli zorunluluklar ve ayrıcalıkların eklenmesi ile edinilen kimliktir. Bu rol ile kişi; bakım isteyen biri olarak kabul edilmek, olağan zorunluluklardan muaf olmak gibi ayrıcalıklara sahip olabilmektedir. Bu durum temaruz olmayıp davranışlara yol açan motivasyon bilinçdışıdır (Kırpınar 2013). Barsky (1992) bu durum için "hasta olma ihtiyacının, iyileştirecek ilacı veya ameliyatı yoktur" ifadelerini kullanmıştır. Craig ve ark. (1994) çalışmasında ikincil kazançların somatize eden kişilerde diğer psikiyatrik bozukluklardan daha yaygın olduğu bulunmuştur. Olumsuz duyguları somatik belirtilerle ifade eden hastalarla ilgili üç neden öne sürmüşlerdir: mizaç ve fizyolojik cevaplarda bireysel farklılıklar; sosyal, kültürel ve dille ilgili etmenler; önceki hastalık deneyimleri. Bu hastaların birçoğunun çocukluklarında ihmal edilmiş olduğu ve yalnızca fiziksel olarak hastalandıklarında diğerleri tarafından fark edilebildikleri ifade edilmiştir. Erken çocukluk deneyimleri "hasta olma” durumunu öğrenmeye yol açabilir. Hastalandığında ebeveynin ilgisini çektiğini veya ailedeki hasta bireyin ilgiyi üzerine topladığını fark eden çocuk hasta kişiyle özdeşim kurmuş olabilir.

Yapılan bu literatür özetinden görüleceği üzere somatizasyon, psikosomatik belirtiler, tıbbi olarak açıklanamayan belirtiler gibi farklı tanımlarla ele alınan bu klinik görünümlerin ortaya çıkmasında ve sürmesinde biyolojik, psikolojik, sosyal ve kültürel etmenlerin tümü rol oynamaktadır. Bu eksenlerin hiçbirinin diğerine göre daha az ya da daha fazla önemli olmadığı da anlaşılmaktadır. Bu durum somatik belirtilerin ruhsal bir bozukluk olarak sınıflandırılmasını zorlaştırmakta olduğu gibi, klinik değerlendirmede de çok yönlü bir hassasiyeti gerektirmektedir.

\section{Temel tedavi yaklaşımı}

Somatik belirti bozukluğunda tedavi yöntemi belirlenirken psikolojik, sosyal ve kültürel etmenler göz önünde bulundurulmalıdır. Tedavi ilkeleri genel olarak; her bir belirtide tekrar başvuru olmasından kaçınmak için düzenli ve kısa aralıklı randevular vermek; başlangıçta genel tıbbi değerlendirme yapıldıktan sonra tanısal testleri sınırlandırmak; fiziksel hastalıkların dışlandığı konusunda güvence vermek; somatik belirtilerle baş etmeye yönelik eğitim vermek; tam kür yerine işlevsellikte iyileşme sağlamak şeklinde hedef belirlemek şeklinde olmalıdır (Abbey ve ark. 2005). Terapötik ilişki kurarken verilen güven; empatik dinleme, tanımlama, yüzleştirme, adlandırma, onaylama şeklinde beş adımla özetlenebilir 
(Allen ve ark. 2006). Hastalara psikoeğitim yapılması oldukça önemlidir. Somatik belirti bozukluğu olan kişilere ağrının beyindeki yolakları, strese verilen somatik tepkiler, egzersiz ve diyetin etkileri gibi konuları içeren bir seanslık psikoeğitim yapıldıktan sonra belirtilerinin belirgin iyileşme gösterdiği bulunmuştur (Johnson ve ark. 2020).

Hekimler somatik belirti bozukluğu olan ve birçok tıbbi prosedürden geçmiş hastalarla sık karşılaşmaktadırlar. Bu grup hastalar klinisyenlerde güçlü emosyonel tepkilere yol açabilmektedir Sıklıkla şikayet eden ve memnun olmayan hastalar karşısında öfke ve zorlanma hissedilebilmektedir (Sharpe ve ark. 1994). Belirtileri fiziksel nedenlerle açıklayamayan hekimler kendi yetkinlikleriyle iddialaşıldığını, hastalar belirtilerini uydurmakla suçlandıklarını düşünebilmektedir (Hahn 2001). Bir grup terapist somatik belirti bozukluğu olan kişilerle çalı̧̧manın hastaların somatik fiksasyonu ve zorlu tanı süreçlerinden geçmeleri nedeniyle zorlayıcı ve bir miktar sinir bozucu olduğunu ifade etmiştir (Weigel ve ark. 2020). Somatik belirti bozukluğu olan çocuk hastaların yönetiminde klinisyenin rolü üzerine yazılmış bir değerlendirmede altta yatan hastalığ 1 teşhis edememe, bunun hastalar ve aileler üzerine etkileri hakkında önemli bir literatür boşluğu olduğu belirtilmiştir. Yazıda özellikle fiziksel bir neden bulunamayışının hastalar ve ailelerde yeterli araştırma yapılmadığı endişesine yol açtığı, hekimlerin bir zihinsel hastalık ya da davranış problemi tanısı koymak yerine kene ısırı̆̆ı, enfeksiyon hastalıkları, fibromiyalji, kronik yorgunluk gibi farklı tıbbi prosedürler de gerektirebilen tanılar koymayı tercih ettiği, ayrıca medikolegal baskının da hekimlerde aşırı tıbbileştirme yolunu seçmelerine neden olduğu vurgulanmıştır (Morabito et al. 2020). Tanıda ve müdahalede gecikme duygudurum ve anksiyete belirtilerinin kötüleşmesine, çoklu uzman başvuruları ve tıbbi testler nedeniyle yüksek maliyetlere sebebiyet verebilmektedir. Kronik somatik belirtiler yüksek düzeyde işlevsellik kaybı ile seyreder. Yaşadıkları sıkıntı tam olarak açıklanamadığında kişiler self medikasyon amacıyla alkol, uyuşturucu maddeler veya kronik opioid analjezik kullanımına başvurulabilmektedir. Geniş tanısal testler, tıbbi prosedürler de iyatrojenik hasar riskini artırmaktadır. Klinisyenlerin hastaya güvence vermek için test istemesinin belirtileri azaltıcı, rahatlatıcı bir etkisi olmadığı gösterilmiştir (D’Souza ve Hooten 2021).

\section{Psikoterapiler}

Psikoterapiler bu hastaların tedavisinde önemli bir yer tutmaktadır. Bilişsel davranış̧̧ı terapi (BDT) en çok kanıt bulunan yöntemdir. Hastalar arası değişiklikler olabilse de tedavi; psikoeğitim, sorun çözme eğitimi, iletişim becerileri, davranışsal aktivasyon, bilişsel yeniden yapılandırma ve gevşeme egzersizlerini içermektedir (Şafak ve Türkçapar 2013). Somatoform bozukluklarda tedavi etkinliklerini değerlendiren bir meta-analiz çalışmasında grup veya bireysel yapılan BDT'nin etkin olduğu gösterilmiştir (Kroenke 2007). BDT ile birlikte mindfulness temelli terapi, psikodinamik terapiler gibi yöntemlerle yapilan randomize kontrollü çalı̧̧maların değerlendirildiği bir meta-analizin sonuçlarına göre tüm çalışmalarda tedavinin sonunda psikoterapilerin yararlı olduğu gösterilmiştir (Van Dessel ve ark. 2014). Daha yakın tarihli bir derlemeye göre çocuklarda somatik belirti bozukluğunda BDT'nin yararlı olduğu gösterilmiştir. Özellikle psikososyal stresörler, sağlık anksiyetesi 
ve felaketleştirme düşünceleri üzerinde çalışılması gerektiği ifade edilmiştir (Tamas ve ark. 2020). Ayrıca bu hastalarda yüz yüze veya uzaktan yapılan emosyonel farkındalık ve duygu ifadesi odaklı terapilerin de belirtileri anlamlı olarak iyileştirdiği gösterilmiştir (Maroti ve ark. 2021). Somatik belirti bozukluğu hastalarının yönetiminin birinci basamakta konsültasyon ile sürdürüldüğü çalışmalarda psikoterapi işlevselliğini artırmada ve tedavi masraflarını azaltmada etkili olurken, belirti şiddetinde değişiklik olmadığı gözlenmiştir (Kroenke 2007). $\mathrm{Bu}$ hastaların tedavisinde belirtilerin şiddetinden ziyade işlevselliği iyileştirmek ve yararsız hastane başvurularını azaltmak hedef olmalıdır.

\section{Farmakoterapi}

Somatik belirti bozukluğu tedavisinde psikososyal yaklaşımlar temel tedavi yöntemi olmakla birlikte ek olarak farmakoterapi de kullanılabilmektedir. Kilavuzlar antidepresan sınıfı ilaçların ancak komorbid depresif belirtilerin varlığında kullanılmasını önermektedir. Farmakoterapinin bu hastalardaki etki mekanizması, psikoterapilere göre daha az anlaşılmıştır (Kleinstauber ve ark. 2014). Tedavilerin çoğunun etkinliğiyle ilgili kanıtlar sınırlıdır. Antidepresanların somatizasyondaki yararının; serotonin ve norepinefrinin inen ağr1 yolaklarındaki analjezik etkisi (Stahl 2002), immün düzenleyici etkilerin yorgunluk gibi belirtilerdeki rolü (Kubera ve ark. 2001), depresyon, anksiyete bozuklukları, travma sonrası stres bozukluğu gibi komorbid tablolarda iyileşme sağlaması (de Waal ve ark. 2004), somatik belirtilerle ilgili organ sistemlerindeki direkt etkileri (trisiklik antidepresanların antikolinerjik etkiyle gastrointestinal geçişi yavaşlatması vb.) (Gorard ve ark. 1994) gibi etkilerle ilgili olabileceği düşünülmektedir.

\section{Sonuç}

Yazıda ruhsal nedenlerle ilişkili olduğu düşünülen somatik belirtilerin geçmişten günümüz tıbbına nasıl ele alındığı gözden geçirilmiş, bu belirtilerin nedenlerine yönelik çalışmalar literatür ışığında özetlenmiştir. Aydınlanma sonrası insan aklının merkeze alınması ile öne çıkan zihin beden ayrımına dair "düalist" görüş üzerine önemli tartışmalar yürütülmüştür. Modern bilim çalı̧̧maları ise zihin ve bedenin birbirinden ayrı ele alınamaz kavramlar olduğuna işaret etmektedir. Konunun düşünce tarihindeki yeri bu yazının amaçları arasında yer almamakla birlikte, söz konusu tartı̧̧maların günümüz psikiyatri pratiğindeki en iyi karşılığ "somatik belirti ve ilişkili bozukluklar" isimli tanı sınıfında yoğunlaşmıştır. Bu bozukluklarda fizyoloji, biyokimya, nörogörüntüleme, genetik, kültür, psikodinamik ve bilişsel kuramlar, travma gibi farklı perspektiflerde çok sayıda araştırma ve tartı̧̧manın yürütüldüğü görülmektedir. Bu çalışmalar da zihin ve bedenin ayrı tutularak ele alınmasının zor olduğunu göstermektedir.

$\mathrm{Bu}$ eski ve derinlikli tartı̧̧mada olduğu gibi sınıflandırma sistemleri de zihinsel, ruhsal belirtilerle ilişkili olduğu düşünülen somatik belirtileri konumlandırmakta zorlanmaktadır. Önceki tanı ölçütleri daha çok belirtilerin "tıbbi olarak açıklanmayan” olmasını öne çıkarırken DSM-5 ile odak bireyin ruhsal tepkilerine çevrilmiştir. Bir psikiyatrik tanı sınıfı tanımlanırken "tıbbi değil” nitelemesinden uzaklaşılması önemli bir gelişmedir. Bu 
değişiklik, söz konusu somatik belirtilerin -yeterli- tıbbi açıklaması olmayışı gerekçesiyle tıp dışı alana itilmesi yerine kişilerin duygu, düşünce ve davranışlarının tıp pratiği içerisinde kapsanması yolunda bir adım olarak değerlendirilebilir.

Ayrıca kişilerin belirtilerinin "bedende değil” şeklinde algılanması, bu belirtileri genel tıbbın dışına atmakta ve kişilerin kendilerini anlaşılmamış, önemsenmemiş hissetmesine neden olabilmektedir (Dimsdale ve ark. 2013). Yeni sınıflama sisteminin öne sürdüğü kavrayış biçimiyle fiziksel hastalığı olan kişilere de sunulacak yaklaşım (psikoeğitim, sosyal faktörlerin düzenlenmesi vb.), gereksiz tetkikler ve tedavileri önlemek açısından yararlı olabilir. Kısa süre önce yayınlanan bir çalışmada somatik belirti bozukluğunda aşırılık görülen belirtiler araştırılmıştır. Genel popülasyonda fiziksel şikayetlere ortalama 30 dakika ayrılırken somatik belirti bozukluğu olan kişilerin ortalama 4 saat belirtileriyle ilgilendikleri görülmüştür. Somatik belirtiler ve ilişkili psikolojik tepkilerin şiddetinin de artmış sağlık hizmeti kullanımı açısından öngördürücü olduğu anlaşılmıştır (Toussaint ve ark. 2021). Fiziksel bir hastalığı olan bireyde somatik belirti bozukluğu tanısı koymak zor ve hassas bir durumdur. Mevcut fiziksel hastalıkla ilişkilendirilemeyen somatik belirtiler için psikiyatrik değerlendirme mutlaka düşünülmelidir. Somatik belirti bozukluğunun biyopsikososyal bütünlükle değerlendirilmesi COVID-19 pandemisi ile birlikte daha da önemli hale gelmiştir. Willis ve Chalder’in (2021) vurguladığ üzere pandemi ile birlikte kişiler somatik belirtileri üzerine daha fazla odaklanmaya ve anlam atfetmeye başlamıştır. Uzamış covid belirtileri olarak tanımlanan belirtilerin birçoğu fiziksel hastalığa ait belirtiler olsa da kişiler bu belirtilerle aşırı miktarda zihinsel uğraşılarda bulunabilir. Bu durumda somatik belirti bozukluğu açısından çok yönlü takibinin yararlı olacağına dikkat çekilmektedir. Bütün bunlara karşın,yazının içeriğinde de söz edilen, yeni tanı kategorisinin güvenilirliği düşük ve fazlasıyla öznel olduğu, ayırıcı tanıda farklı tıbbi durumların gözden kaçmasına neden olabileceğine dair görüşlerin de dikkate alınması gerekmektedir.

Sonuç olarak tedavisinin zor olduğu konusunda uzmanların hemfikir olduğu bu bozukluğun sınıflandırmasıyla ilgili tartışmaların henüz çok yolu var gibi görünmektedir. Klinik pratikte bu belirtilerin biyopsikososyal bir bütünlük içinde ele alınması, hasta hekim arasındaki güven ilişkisine özel hassasiyet gösterilmesi, hastanın gereksinimleri gözetilerek psikososyal yaklaşımların ve diğer tedavi seçeneklerinin kullanılması oldukça önemlidir.

\section{Kaynaklar}

Abbey SE, Wulsin L, Levenson $J$ (2005) Somatization and somatoform disorders, Textbook of Psychosomatic Medicine (Ed JL Levenson):261-269. Washington DC, American Psychiatric Publishing.

Algül A, Tütüncü R (2013) Bir somatizasyon biçimi olarak ağrı: Psikiyatrik değerlendirme ve tedavisi. Psikiyatride Güncel, 3:52-59.

Allen LA, Woolfolk RL, Escobar JI, Gara MA, Hamer RM (2006) Cognitive-behavioral therapy for somatizaton disorder: a randomized controlled trial. Arch Intern Med, 166:1512-1518.

APA (1980) Diagnostic and Statistical Manual of Mental Disorders 3rd edition (DSM-III). Washington DC, American Psychiatric Association.

APA (2000) Diagnostic and Statistical Manual of Mental Disorders 4th edition text revision (DSM-IV-TR). Washington DC, American Psychiatric Association.

APA (2013) Diagnostic and Statistical Manual of Mental Disorders 5th edition (DSM-5). Washington DC, American Psychiatric Association. 
Anderson G, Maes M, Berk M (2012) Biological underpinnings of the commonalities in depression somatization and chronic fatigue syndrome. Med Hypotheses, 78:752-756.

Atmaca M, Sirlier B, Yildirim H, Kayali A (2011) Hippocampus and amygdalar volumes in patiens with somatization disorder. Prog Neuropsychopharmacol Biol Psychiatry, 35:1699-1703.

Atmaca M (2012) Somatoform bozukluklarda nörogörüntüleme: Bir gözden geçirme. Türk Psikiyatri Derg, 23:274-280.

Ball SG, Desaiah D, Spann ME, Zhang Q, Russell JM, Robinson MJ et al. (2011) Efficacy of duloxetine on painful physical symptoms in major depressive disorder for patients with clinically signifizant painful physical symptoms at baseline: A meta-analysis of 11 doubleblind, placebo-controlled clinical trials. Prim Care Companion CNS Disord, 13:PCC. 11 r01181.

Barsky AJ (1992) Amplification, somatization and the somatoform disorders. Psychosomatics, 33:28-34.

Barsky AJ (2016) Assessing the New DSM-5 diagnosis of somatic symptom disorder. Psychosom Med, 78:2-4.

Berry DS, Pennebaker JW (1993) Nonverbal and verbal emotional expression and health. Psychother Psychosom, 59:11-19.

Beyazyüz M, Göka E (2013) Kültür ve somatizasyon. Psikiyatride Güncel, 3:17-26.

Boeckle M, Schrimpf M, Liegl G, Pieh C (2016) Neural correlates of somatoform disorders from a meta-analytic perspective on neuroimaging studies. Neuroimage Clin, 11:606-613.

Bourke JH, Langford RM, White PD (2015) The common link between functional somatic syndromes may be central sensitisation. J Psychosom. Res, 78:228-236.

Breuer J, Freud S (1895) Studies on Hysteria. New York, Hafner Publishing Co.

Cao J, Wei J, Fritzsche K, Toussaint AC, Li T, Jiang Y et al. (2020) Prevalence of DSM-5 somatic symptom disorder in Chinese outpatients from general hospital care. Gen Hosp Psychiatry, 62:63-71.

Choi E, Chentsova-Dutton Y, Parrott WG (2016) The Effectiveness of somatization in communicating distress in Korean and American cultural contexts. Front Psychol, 7:383.

Colak B, Eken A, Kusman A, Akaslan D, Kizlpınar S, Cakmak I et al (2021) The relationship of cortical activity induced by pain stimulation with clinical and cognitive features of somatic symptom disorder: A controlled functional near infrared spectroscopy study. J Psychosom Res, 140:110300.

Craig TK, Drake H, Mills K, Boardman P (1994) The South London Somatisation Study. II. Influence of stressful life events, and secondary gain. Br J Psychiatry, 165:248-258.

Çetin Ş (2018) Bedensel belirti bozukluğu olan hastalarda epigenetik değişiklikler, duygu tanıma ve ifade becerisi ile travmatik yaşantıları ilişkisi (Uzmanlık tezi). Denizli, Pamukkale Üniversitesi.

Dannlowski U, Stuhrmann A, Beutelmann V, Zwanzger P, Lenzen T, Grotegerd D et al (2012) Limbic scars: long-term consequences of childhood maltreatment revealed by functional and structural magnetic resonance imaging. Biol Psychiatry, 71:286-293.

de Waal MW, Arnold IA, Eekhof JA, van Hemert AM (2004) Somatoform disorders in general practice: prevalence, functional impairment and comorbidity with anxiety and depressive disorders. Br J Psychiatry, 184:470-476.

Dimsdale JE, Creed F, Escobar J, Sharpe M, Wulsin L, Barsky A et al. (2013) Somatic symptom disorder: An important change in DSM. J Psychosom Res, 75:223-228.

Dinan T (2001) Novel approaches to the treatment of depression by modulating the hypothalamic pituitary adrenal axis. Hum Psychopharmacol, 16:89-93.

D'Souza RS, Hooten WM (2021) Somatic syndrome disorders. In: StatPearls [Internet]. Treasure Island (FL), StatPearls Publishing.

Escobar Jl, Canino G (1989) Unexplained physical complaints: psychopathology and epidemiological correlates. Br J Psychiatry, 154:24-27.

Espiridion E D, Kerbel S A (2020) A systematic literature review of the association between somatic symptom disorder and antisocial personality disorder. Cureus, 12:e9318.

Ford CV (2000) Somatoform disorders. In Current Diagnosis and Treatment Psychiatry. (Eds MH Ebert, PT Loosen, B Nurcombe):366-377. New York, McGraw-Hill.

Frances A (2013) The new somatic symptom disorder in DSM-5 risks mislabeling many people as mentally ill. BMJ, 346:f1580.

Frodl T (2016) Do (epi)genetics impact the brain in functional neurologic disorders? Handb Clin Neurol, 139:157-165.

Gorard DA, Libby GW, Farthing MJ (1994) Influence of antidepressants on whole gut and orocecal transit times in health and irritable bowel syndrome. Aliment Pharmacol Ther, 8:159-166. 
Hahn SR (2001) Physical symptoms and physician-experienced difficulty in the physician-patient relationship. Ann Intern Med, 134:897-904.

Hakala M, Karlsson H, Kurki T, Aalto S, Koponen S, Vahlberg et al (2004) Volumes of the caudate nuclei in women with somatization disorder and health women. Psychiatry Res, 131:71-78.

Hakala M, Vahlberg T, Niemi PM, Karlsson H (2006) Brain glucose metabolism and temperament in relation to severe somatization. Psychiatry Clin Neurosci, 60:669-675.

Harrison NA, Brydon L, Walker C, Gray MA, Steptoe A, Critchley HD (2009) Inflammation causes mood changes through alterations in subgenual cingulate activity and mesolimbic connectivity. Biol Psychiatry, 66:407-414.

Heim C, Ehlert U, Hellhammer DH (2000) The potential role of hypocortisolism in the pathophysiology of stres related bodiliy disorders. Psychoneuroendocrinology, 25:1-35.

Hollfield MA (2005) Somatoform disorers. In Kaplan\&Sadock's Comprehensive Textbook of Psychiatry, 8th edition (Ed. BJ Sadock, VA Sadock):1800-1828. Philadelphia, PA, Lippincott Williams \& Wilkins.

Hüsing P, Löwe B, Toussaint A (2018) Comparing the diagnostic concepts of ICD-10 somatoform disorders and DSM-5 somatic symptom disorders in patients from a psychosomatic outpatient clinic. J Psychosom Res, 113:74-80.

Johnson K, Bennett C, Rochani H (2020) Significant improvement of somatic symptom disorder with brief psychoeducational intervention by PMHNP in primary care. J Am Psychiatr Nurses Assoc, 23:1078390320960524.

Lipowski Z (1988) Somatization: The concept and its clinical application. Am J Psychiatry, 145:1358-1368.

Kırpınar I (2013) Somatizasyon ve somatoform bozukluklar: Uygulamaya yansıyan anlam karmaşası. Psikiyatride Güncel, 3(1):1-16. Kırpınar i (2019) Somatizasyon ve bedensel belirti bozuklukları. In Konsültasyon Liyezon Psikiyatrisi Cilt 1, (Ed. H.Elbi, C. Cimilli, Ö. Önen Sertöz, Ç.Karşıdağ, G. Sözeri-Varma). Ankara, Türkiye Psikiyatri Derneği.

Kidd BL, Urban LA (2001) Mechanisms of inflammatory pain. Br J Anaesth, 87:3-11.

Kirmayer LJ, Young A (1998) Culture and somatization: clinical, epidemiological and ethnographic perspectives. Psychosom Med, 60:420-430.

Kirmayer LJ, Ryder AG (2016) Culture and psychopathology. Curr Opin Psychol, 8:143-148.

Kleinstauber M, Witthöft M, Steffanowski A, van Marwijk H, Hiller W, Lambert MJ (2014) Pharmacological interventions for somatoform disorders in adults. Cochrane Database Syst Rev, 11:CD010628.

Knesebeck 0, Lehmann M, Löwe B, Lüdecke D (2020) Causal attributions for somatic symptom disorder. J Psychosom Res, 129:109910.

Krause D, Kirnich VB, Stapf TM, Hennings A, Riemer S, Riedel M et al. (2019) Values of cytokines and tryptophan metabolites over a 12 weeks time course in patients with depression and somatoform disorder. Clin Psychopharmacol Neurosci, 28; 17:34-42.

Kroenke K (2007) Efficacy of treatment for somatoform disorders: a review of randomized controlled trials. Psychosom Med, 69:881888.

Kubera N, Lin AH, Kenis G, Bosmans E, van Bockstaele D, Maes M (2001) Anti-inflammatory effects of antidepressants through suppression of the interferon-gamma/interleukin-10 production ratio. J Clin Psychopharmacol, 21:199-206.

Mai F (2004) Somatization disorder: A practical review. Can J Psychiatry, 49:652-662.

Maroti D, Ek J, Widlund R, Schubiner H, Lumley M, Lilliengren P et al. (2021) Internet-administered emotional awareness and expression therapy for somatic symptom disorder with centralized symptoms: A preliminary efficacy trial. Front Psychiatry, 12:620359.

Maunder RG, Hunter JJ, Atkinson L, Steiner M, Wazana A, Fleming AS et al. (2017) An attachment-based model of the relationship between childhood adversity and somatization in children and adults, Psychosom Med, 79:506-513.

Mayou R (2014) Is the DSM-5 chapter on somatic symptom disorder any better than DSM-IV somatoform disorder? Br J Psychiatry, 204:418-419.

Morabito G, Barbi E, Cozzi G (2020) The unaware physician's role in perpetuating somatic symptom disorder. JAMA Pediatr, 174:9-10. Öztürk 0, Uluşahin A (2016) Ruh Sağlığı ve Bozuklukları, 14.Baskı. Ankara, Nobel Tıp Kitabevleri.

Paras ML, Murad MH, Chen LP, Goranson EN, Sattler AL, Colbenson KM et al (2009) Sexual abuse and lifetime diagnosis of somatic disorders: a systematic review and meta-analysis. JAMA, 302:550-561.

Pan X, Ding W, Sun X, Ji C, Zhou Q, Yan C et al (2021) Gray matter density of the dorsomedial prefrontal cortex mediates the relationship between catastrophizing and anxiety in somatic symptom disorder. Neuropsychiatr Dis Treat, 17:757-764.

Pennebaker JW, Watson D (1991) The Psychology of somatic symptoms. In Progress in psychiatry, No. 31. Current Concepts of Somatization: Research and Clinical Perspectives (Eds. LJ Kirmayer, JM Robbins): 21-36. Washington, American Psychiatric Press. 
Pukhalsky AL, Shmarina GV, Alioshkin VA, Sabelnikov A (2008) HPA axis exhaustion and regulatory T cell accumulation in patients with a functional somatic syndrome: recent view on the problem of Gulf War veterans. J Neuroimmunol, 196:133-138.

Rief W, Hennings A, Riemer S, Euteneuer F (2010) Psychobiological differences between depression and somatization. J Psychosom Res, 68:495-502.

Rossetti MG, Delvecchio G, Calati R, Perlini C, Bellani M, Brambilla P (2021) Structural neuroimaging of somatoform disorders: A systematic review. Neurosci Biobehav Rev, 122:66-78.

Şafak Y, Türkçapar H (2013) Somatoform bozukluklarda bilişsel davranış̧ı terapi. Psikiyatride Güncel, 3:84-94.

Sahin E, Caykoylu A, Senat A, Erel 0 (2019) A comprehensive study of oxidative stress in patients with somatic symptom disorder. Acta Neuropsychiatr, 31:100-105.

Schwarz MJ, Spath M, Müller-Bardoff H, Pongrtz DE, Nondy B, Ackenheil M (1999) Relationship of substance P, 5-hydroxyindole acetic acid and tryptophan in serum of fibromyalgia patients. Neurosci Lett, 259:196-198.

Sharpe M, Mayou R, Seagroatt V, Surawy C, Warwick H, Bulstrode C et al (1994) Why do doctors find some patients difficult to help? Q J Med, 87:187-193.

Smith JK, Józefowicz RF (2012) Diagnosis and treatment of somatoform disorders. Neurol Clin Pract, 2:94-102.

Stahl SM (2002) The psychopharmacology of painful physical symptoms in depression. J Clin Psychiatry, 63:382-383.

Taycan 0, Sar V, Celik C, Erdogan-Taycan S (2014) Trauma-related psychiatric comorbidity of somatization disorder among women in eastern Turkey. Compr Psychiatry, 55:1837-1846.

Tamas R, Perczel-Forintos D, Mate 0, Gyenge Z (2020) Treatment of somatic symptom disorder in childhood: evidence-based psychotherapy interventions. Orv Hetil, 161:1050-1058.

Toussaint A, Hüsing P, Kohlmann S, Brahler E, Löwe B (2021) Excessiveness in symptom-related thoughts, feelings, and behaviors: An investigation of somatic symptom disorders in the general population. Psychosom Med, 83:164-170.

Ünal S (1999) Somatoform bozukluklar; nozoloji ve tarihçe. Türkiye Klinikleri Psikiyatri Dergisi, 1:1-6.

Ünal S (2002) Bir anlatım tarzı olarak bedenselleştirme. Anadolu Psikiyatri Derg, 3:52-55.

Van Dessel N, den Boeft M, van der Wouden JC, Kleinstauber M, Leone SS, Terluin B et al (2014) Non-pharmacological interventions for somatoform disorders and medically unexplained physical symptoms (MUPS) in adults. Cochrane Database Syst Rev, 1:CD011142.

Waller E, Scheidt CE, Hartmann A (2004) Attachment representation and illness behavior in somatoform disorders. J Nerv Ment Dis, 192:200-209.

Weigel A, Maehder K, Witt M, Löwe B (2020) Psychotherapists' perspective on the treatment of patients with somatic symptom disorders. J Psychosom Res, 138:110228.

Willis C, Chalder T (2021) Concern for covid-19 cough, fever and impact on mental health. What about risk of Somatic Symptom Disorder? J Ment Health, 1:1-5.

Yazarların Katkıları: Yazarlar çalışmaya önemli bir bilimsel katkı sağladıklarını ve makalenin hazırlanmasında veya gözden geçirilmesinde yardımcı olduklarını kabul etmişlerdir.

Danışman Değerlendirmesi: Dış bağımsız.

Çıkar Çatışması: Yazarlar çıkar çatışması bildirmemiştir.

Finansal Destek: Yazarlar bu çalışma için finansal destek almadı̆̆ını beyan etmiştir.

Authors Contributions: The authors attest that they have made an important scientific contribution to the study and have assisted with the drafting or revising of the manuscript.

Peer-review: Externally peer-reviewed.

Conflict of Interest: No conflict of interest was declared by the authors.

Financial Disclosure: The authors declared that this study has received no financial support. 